\title{
25 år siden Sovjetunionens oppløsning
}

Det er i år 25 år siden Sovjetunionens oppløsning, med alle de vidtrekkende økonomiske, politiske og sosiale endringene som fulgte. I ettertid oppfattes Sovjetunionens sammenbrudd ofte som noe uunngåelig, og det er vanskelig å tenke seg hvordan verden kunne vært om historien hadde tatt andre veier.

Dermed er det nå også vanskelig å forestille seg hvor usannsynlig en verden uten Sovjetunionen en gang virket. Alexei Yurchak har i tittelen på sin bok om den siste sovjetiske generasjonen på poetisk vis oppsummert hvordan det var å leve gjennom Sovjetunionens oppløsning: Everything was forever, until it was no more (Princeton University Press 2013). Også utenfor Sovjetunionen var det knapt noen som hadde forutsett de enorme endringene som i løpet av få år forandret verden.

Når Sovjetunionen først var borte, derimot, var troen på forandringer stor. Anført av Francis Fukuyamas formulering om «historiens slutt» var det hos mange i Vesten en forventning og et håp om at de tidligere kommunistlandene ville gå gjennom en «transisjon» til demokrati og markedsøkonomi etter en vestlig modell. I mange tilfeller har det ikke blitt slik (med landene som hadde EU-medlemskap som et realistisk mål som viktige unntak). Og fortsatt er det nok slik at vi ofte overvurderer mulighetene for rask endring i land som gjerne vil bli en del av det vestlige fellesskapet.

1990-tallet var kaotisk og vanskelig i mange tidligere kommunistland, og minnet om denne tiden fortsetter å ha politisk betydning. Uten å ta i betraktning folks erfaringer fra den tiden er det for eksempel vanskelig å forstå hvorfor russiske myndigheters vektlegging av stabilitet har hatt så stor gjenklang i befolkningen. Spørsmål om hva politikken skal oppnå blir tett sammenvevd med spørsmål om hva politikken $i k k e$ skal føre til.

I denne utgaven av Nordisk Østforum ser Jakub M. Godzimirski nærmere på et land i Europa som er ansett for å ha gått gjennom en svært vellykket overgang til demokrati og markedsøkonomi, nemlig Polen. Men heller ikke her er utviklingen entydig. Godzimirski skriver om hvordan polske velgere har stemt frem en «illiberal vending» ved å gi Lov- og rettferdighetspartiet (PiS) regjeringsmakten. Artikkelen viser hvordan Polen - i øynene til mange i EU - har gått fra å være en europeisk «suksesshistorie» til heller å være et europeisk «problembarn».

Den andre fagartikkelen i dette nummeret retter blikket vekk fra det storpolitiske maktspillet. I stedet skriver Tatiana Wara om tidligere sovjetborgere, nærmere bestemt 
russiske kvinner i Nord-Norge. Wara skriver om hvordan erindringer fra sovjetisk fortid knyttes til konkrete praksiser, for eksempel plukking av sopp i skogen. Soppturene får Waras informanter til å tenke tilbake på barndommen i Sovjetunionen, på sovjetiske tradisjoner og ideologi. Minnet om livet i Sovjetunionen, og om hvordan unionens oppløsning forandret hverdagslivet, er noe de alltid vil bære med seg.

Kristian Lundby Gjerde og Natalia Moen-Larsen 